\title{
Dietary fat and $N$-nitrosation in the rat
}

\author{
BY F. W. WARD AND M. E. COATES* \\ The Robens Institute, University of Surrey, Guildford, Surrey GU2 $5 X H$
}

(Received 14 October 1986 - Accepted 19 March 1987)

1. Groups of four conventional $(\mathrm{CV})$ rats ate natural or purified diets either with or without $100 \mathrm{~g}$ fat $/ \mathrm{kg}$ and drank $0.235 \mathrm{M}$-sodium nitrate. The fats tested were butterfat, coconut oil, olive oil, maize oil and safflower oil.

2. Decreased urinary excretion of $N$-nitrosoproline (NPRO) was observed in rats fed on fat-supplemented diets compared with those fed on low-fat diets, with butterfat having the greatest effect of the fats tested.

3. Reduced excretion of NPRO was not the result of inhibition of the intragastric $N$-nitrosation reaction or absorption of nitrosamine from the gastrointestinal tract.

4. The availability of nitrite in aqueous solution was decreased by the fat diets but the effect was similar in all the fats tested.

5. Nitrate reductase activity was present in the forestomach contents of $\mathrm{CV}$ rats at $\mathrm{pH}>4$ and was apparently inhibited by feeding a fat diet. No nitrate reductase activity was detected in stomach contents of germ-free rats.

6. Nitrate reductase activity in stomach and small intestinal tissue was not altered by feeding a fat diet.

7. It was concluded that nitrate reductase activity in stomach contents was of microbial origin and the decreased urinary excretion of NPRO on feeding the fat diets was mainly due to the inhibition of nitrate reductase activity in stomach contents.

Nitrate is commonly present in the diet, the principal source being vegetables which accumulate the ion, e.g. celery (Apium graveolens) and lettuce (Lactuca sativa). It also occurs in tap-water and cured meats. Its potential toxicity depends on its reduction to nitrite by the action of bacterial and mammalian enzymes and the subsequent reaction of nitrite with secondary and tertiary amines to form $N$-nitrosamines. The nitrosation reaction can proceed non-enzymically at acid $\mathrm{pH}$.

It was reported by Kato \& Kikugawa (1984) that in vitro $N$-nitrosation of dimethylamine by nitrite was decreased in the presence of unsaturated fatty acid esters. Exploratory experiments in vitro in this laboratory confirmed that $N$-nitrosation was reduced in the presence of a variety of fats and unsaturated fatty acid esters, but as butterfat was consistently more inhibitory than coconut, olive, maize or safflower oils, the degree of unsaturation did not appear to be a prime factor in the inhibitory process.

The experiments reported here were done to investigate whether $N$-nitrosation in vivo in rats was influenced by dietary fats and, if so, to explore possible mechanisms of inhibition. $N$-nitrosation in vivo was monitored by measuring urinary excretion of $N$-nitrosoproline (NPRO), a stable nitrosated amine that is considered to be a reliable index of $N$-nitrosation reactions in vivo.

Although the results of experiments in vivo established that nitrosamine excretion was lower when any of a range of fats was included in the diet, they gave no evidence of inhibition of the nitrosation reaction. Later investigations were therefore directed to the formation and availability of nitrite. Attention was concentrated on butterfat, which was the most effective in lowering nitrosamine excretion in vivo. 
Table 1. Composition of purified diets $(\mathrm{g} / \mathrm{kg})$

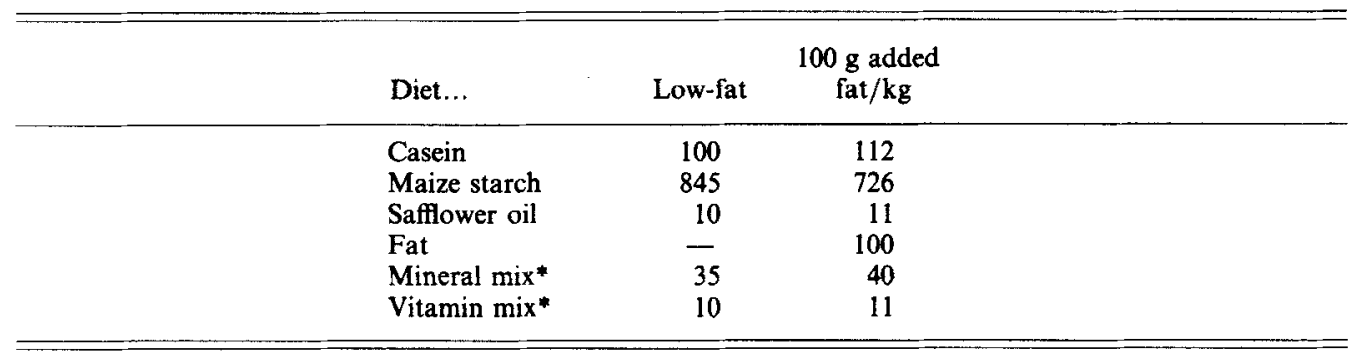

* In the low-fat diet the mineral and vitamin mixes provided the following quantities of salts and vitamins $(\mathrm{g} / \mathrm{kg})$, values in parentheses denoting values for the added fat diet: potassium citrate monohydrate 10.1 (11-6), magnesium sulphate heptahydrate $4.9(5.6)$, sodium chloride $1.3(1.5)$, calcium carbonate $8.5(9.7)$, calcium tetrahydrogen diorthophosphate monohydrate $9.7(11.0)$, sodium metasilicate pentahydrate $185(212) \mathrm{mg}$, ferric citrate $212(243) \mathrm{mg}$, manganous carbonate $106(121) \mathrm{mg}$, zinc carbonate trihydrate $21(25) \mathrm{mg}$, nickel sulphate 14 (16) mg, cupric carbonate monohydrate 10 (11) mg, stannic chloride pentahydrate $2894(3307) \mu \mathrm{g}$, sodium fluoride $2263(2586) \mu \mathrm{g}$, ammonium metavanadate $1113(1272) \mu \mathrm{g}$, chromic chloride hexahydrate 965 (1102) $\mu \mathrm{g}$, sodium selenite $334(382) \mu \mathrm{g}$, potassium iodide $185(212) \mu \mathrm{g}$, ammonium molybdate 74 (85) $\mu \mathrm{g}$, biotin 600 (600) $\mu \mathrm{g}$, choline chloride $1 \cdot 3(1.5) \mu \mathrm{g}$, pteroylmonoglutamic acid 6 (6.6) $\mu \mathrm{g}$, myo-inositol $200(220) \mathrm{mg}$, menadione sodium bisulphite $150(165) \mu \mathrm{g}$, nicotinamide 90 (99) $\mathrm{mg}$, pyridoxine hydrochloride 42 (46) $\mathrm{mg}$, calcium pantothenate 48 (53) mg, retinyl palmitate (Rovimix A-500) 24 (26) $\mathrm{mg}$, riboflavin $36(40) \mathrm{mg}$; thiamin hydrochloride 36 (40) mg, cholecalciferol 25 (27) $\mu \mathrm{g}$, cyanocobalmin 30 (33) $\mu \mathrm{g}$.

\section{MATERIALS AND METHODS}

\section{Animals and diets}

Most experiments were performed on conventional (CV) rats housed in the open laboratory. Young rats of the Wistar, Fischer or Lister Hooded strains, bred on the premises were used. They were housed in groups in standard rat cages with mesh floors except when excreta were to be collected. For this purpose, they were transferred to individual metabolism cages a few days before the collection was due to begin. Germ-free (GF) rats were maintained in plastic isolators as previously described (Ward et al. 1986).

The animals were fed on a natural rat diet (LAD-2; K \& K Greeff, Croydon, Surrey) or a purified diet with or without $100 \mathrm{~g}$ fat $/ \mathrm{kg}$. Since the inclusion of fat increased the energy density of the diet, the protein, vitamin and mineral supplements of the purified diets were adjusted to be in the same proportion relative to energy in the fat-supplemented diets as in the low-fat diet. The formulas are given in Table 1. Diets for GF rats and their CV controls were sterilized by gamma radiation at $50 \mathrm{kGy}$. Butterfat was prepared by stirring a sample of unsalted butter in four times its weight of hot distilled water and allowing the fat to separate. The other fats were obtained from Sigma Chemical Co. Ltd, Poole, Dorset.

\section{Analytical methods}

Nitrite determination. The approximate nitrite concentrations of the test solutions were determined using Merckoquant nitrite test strips (E. Merck, Darmstadt, W. Germany). A more accurate analysis was then performed following the method of Shechter et al. (1972), but $N$-1-napthylethylenediamine dihydrochloride (Sigma Chemical Co. Ltd) was used for the coupling reaction instead of 1-napthylamine-7-sulphonic acid and the absorbance of solutions read at $543 \mathrm{~nm}$.

$\mathrm{N}$-nitrosation determination. $N$-nitrosoproline (NPRO) was analysed on a Hewlett Packard 5580A gas-liquid chromatograph (GLC) coupled to a thermal-energy analyser 
(Thermoelectron Corp, Mass., U.S.A.) using the modified method of Ohshima (1983) as described by Ward et al. (1986). Acidified aqueous samples were extracted with ethyl acetate on Extrelut columns (E. Merck) and following concentration on a rotary evaporator at $50^{\circ}$ a diethyl ether solution of diazomethane was used to methylate the extracts. Separation was achieved in a glass column packed with $10 \%$ Carbowax $20 \mathrm{~m}$ on Chromosorb W-HP, $100-120$ mesh, and heated to $185^{\circ}$. The injection port temperature was $200^{\circ}$.

$N$-nitrosodimethylamine (NDMA) was extracted twice from aqueous solution with $10 \mathrm{ml}$ chloroform and the volume made up to $25 \mathrm{ml}$. The sample was injected directly on to the GLC column heated to $140^{\circ}$ without further treatment.

\section{Measurement of nitrate reductase activity}

Nitrate reductase activity was measured in homogenates of the stomach and small intestine and in the stomach contents over a range of $\mathrm{pH}$ values. The samples were homogenized in an appropriate volume of sterile buffer at the required $\mathrm{pH}$ containing $0.235 \mathrm{M}$-sodium nitrate and incubated for $24 \mathrm{~h}$ at $37^{\circ}$. The nitrite content of the incubates was determined as described previously. The specific nitrate reductase involved is unknown.

Preparation of samples. Measurements were made on whole stomachs with contents, on whole-stomach tissue, on portions of the stomach or small intestine and on the stomach contents. The animals were killed by cervical dislocation and the abdomen opened. Where necessary a clamp was placed between the forestomach and glandular stomach before the required tissue and contents were removed. The contents were suspended in either KrebsRinger phosphate (KRP) buffer at $\mathrm{pH} 7.4$ or $0.1 \mathrm{M}$-citrate buffer ranging in $\mathrm{pH}$ from 2 to 7. The tissues were homogenized in $15 \mathrm{ml}$ of either ice-cold KRP buffer at $\mathrm{pH} 7.4$ or $0.1 \mathrm{M}$-citrate buffer at $\mathrm{pH} 4.0$.

With the exception of Expt 11, a homogenizer was used in experiments with CV rats but could not conveniently be introduced into the GF isolators. The samples of GF tissue were ground by hand in a mortar with sterilized sand, 40-100 mesh (BDH Chemicals Ltd, Poole, Dorset) and cold sterile buffer. The suspension was transferred to incubation bottles which were sealed before removal from the isolator. In Expt 11, tissue from CV rats were ground with sterilized sand, approximating the conditions under which GF tissue in a similar experiment was prepared.

\section{Statistical analysis}

Analysis of variance was done on the results of experiments with more than one experimental treatment. Student's $t$ test was used to calculate significance of difference between means of two treatments.

\section{EXPERIMENTAL PROCEDURE}

Experiments in vivo

Three experiments were done to investigate the effects of dietary fats on $N$-nitrosamine excretion by male CV Wistar rats aged 4 weeks at the beginning of the experimental period.

Expt 1. Groups of four rats were fed for 3 weeks on the natural diet or the same diet in which $100 \mathrm{~g} / \mathrm{kg}$ had been replaced by butterfat or maize oil. All diets were supplemented with $10 \mathrm{~g} \mathrm{1-proline} / \mathrm{kg}$ and the distilled drinking water contained $0.235 \mathrm{M}-\mathrm{NaNO}_{3}$. Urine was collected in $5 \mathrm{ml} 1 \mathrm{M}$-sodium hydroxide over the final $24 \mathrm{~h}$ and analysed for NPRO.

Expt 2. This experiment followed a similar pattern to that of Expt 1 except that the fats tested were coconut, olive and safflower oils.

Expt 3. Groups of four rats were fed for 3 weeks on the purified casein diet 
unsupplemented with 1-proline or a diet with the same protein:energy value containing $100 \mathrm{~g}$ fat $/ \mathrm{kg}$. The fats examined were butterfat, coconut, olive, maize and safflower oils. The distilled drinking water contained $0.235 \mathrm{M}-\mathrm{NaNO}_{3}$. In an attempt to reduce variability in excretion of NPRO, urine was collected daily in $5 \mathrm{ml} 1 \mathrm{M}-\mathrm{NaOH}$ over $7 \mathrm{~d}$ and a portion analysed for NPRO.

Expt 4. This was done to determine whether the reduced content of urinary NPRO in animals given the fat-containing diets might be the result of delayed absorption or excretion rather than a genuine interference with $N$-nitrosamine formation. Two groups of four rats were fed on the natural diet with or without $100 \mathrm{~g}$ butterfat $/ \mathrm{kg}$ for 3 weeks. At the end of the feeding period they were given a single dose of $10 \mathrm{mg}$ NPRO in $1 \mathrm{ml}$ distilled water by stomach tube. Urine and faeces were collected through the following $24 \mathrm{~h}$ in $5 \mathrm{ml}$ $1 \mathrm{M}-\mathrm{NaOH}$ and analysed for NPRO.

\section{Experiments in vitro}

Expt 5. This was an investigation of the effects of butterfat on the $\mathrm{pH}$ of the stomach contents and formation therein of $N$-nitrosamines. Groups of five male and five female $\mathrm{CV}$ Lister Hooded rats aged 6 weeks were fed for 2 weeks on the purified diet with or without $100 \mathrm{~g}$ butterfat $/ \mathrm{kg}$. At the end of that period they were killed. The contents of the forestomach and glandular stomach were collected separately in $15 \mathrm{ml}$ distilled water.

The $\mathrm{pH}$ of the suspension was measured and after the addition of $0.10 \mathrm{mmol}$ each of sodium nitrite and amidopyrin (BDH Chemicals Ltd) in $0.5 \mathrm{ml}$ distilled water the suspension was incubated for $2 \mathrm{~h}$ at $37^{\circ}$ with constant shaking. NDMA formation was assayed as described previously.

Expt 6. This examined the nitrite-binding effects of the purified diet with or without the addition of butterfat, coconut oil, olive, maize and safflower oils. A portion $(2 \mathrm{~g})$ of each diet was suspended in $15 \mathrm{ml} 0.1 \mathrm{M}$-citrate buffer, $\mathrm{pH} 4.0$ and $0.10 \mathrm{mmol} \mathrm{NaNO}_{2}$ in $0.5 \mathrm{ml}$ distilled water was added and the suspension incubated for $2 \mathrm{~h}$ at $37^{\circ}$ with constant shaking. At the end of this period the suspension was shaken with $10 \mathrm{ml}$ distilled water, centrifuged and the concentration of nitrite in the supernatant fraction assayed.

Expt 7. This was done to determine the effects of butterfat on nitrate reductase activity in the stomach and small intestine. Groups of four male CV Wistar rats, aged 6 weeks, were fed on the purified diet with or without butterfat for 2 weeks. The distilled drinking water contained $0.235 \mathrm{M}-\mathrm{NaNO}_{3}$. At the end of this period the animals were killed and nitrate reductase activity in the stomach assayed at $\mathrm{pH} 4.0$ and $\mathrm{pH} 7.4$ to give an indication of the contributions from microbial activity in stomach contents and tissue respectively. Activity in the small intestine was assayed at $\mathrm{pH} 7 \cdot 4$.

Expt 8. Nitrate reductase activity in the stomach contents of the CV rat was investigated over a range of $\mathrm{pH}$ values. Six male $\mathrm{CV}$ Wistar rats 6 weeks old, were fed on the purified diet for 2 weeks and drank a solution of $0.235 \mathrm{M}-\mathrm{NaNO}_{3}$ after which they were killed and the contents from their forestomachs and glandular stomachs separately collected. The contents from each part of the stomach were pooled and diluted with their own volume of $0 \cdot 145 \mathrm{M}$-sodium chloride in distilled water. Nitrate reductase activity of a $1 \mathrm{ml}$ suspension was determined at $\mathrm{pH} 2-7$.

Expt 9. To determine whether the nitrate reductase activity in stomach contents was of microbial or mammalian origin an experiment similar to Expt 8 was conducted on three male and three female 11-month-old GF Fischer rats. Portions of forestomach tissue and glandular stomach tissue were also assayed for their nitrate reductase activity.

Expt 10. It was observed in preliminary experiments that the quantity of fat-containing diet present in the stomach at the time of sampling appeared to influence the amount of nitrite formed during a $24 \mathrm{~h}$ incubation period. This experiment was done to determine 
whether the addition of a fat-containing diet to incubation samples influenced the appearance of nitrite in the incubation medium. Groups of four male CV Wistar rats, 6 weeks old, ate the purified diet with or without $100 \mathrm{~g}$ butterfat $/ \mathrm{kg}$ and drank a solution of $0.235 \mathrm{M}-\mathrm{NaNO}_{3}$ for $6 \mathrm{~d}$ after which the stomach contents and tissue were collected. Wholestomach tissue was homogenized and stomach contents suspended in buffer, $\mathrm{pH} 7 \cdot 4,2 \mathrm{~g}$ of either low-fat or $100 \mathrm{~g}$ butterfat $/ \mathrm{kg}$ diet added and the nitrate reductase activity of the samples determined.

Expt 11. To reduce variation in the amount of food present in the stomachs at the time of sampling, rats were fasted overnight and then allowed access to food for a controlled period. Groups of twelve male CV Wistar rats were fed on a purified low-fat diet or one containing $100 \mathrm{~g}$ butterfat $/ \mathrm{kg}$ and drank a solution of $0.235 \mathrm{M}-\mathrm{NaNO}_{3}$ for $6 \mathrm{~d}$. They were then fasted overnight for $18 \mathrm{~h}$. One group of four rats on each dietary regimen was then killed and groups of four of the others were allowed access to food for either 1 or $6 \mathrm{~h}$ before they were killed. Nitrate reductase activity was measured in stomach tissue and stomach contents at $\mathrm{pH} 7 \cdot 4$.

Expt 12. An experiment similar to Expt 11 was done on groups of six male and six female GF Fischer rats 6 weeks old.

\section{RESULTS}

\section{$\mathrm{N}$-nitrosation and nitrite availability experiments}

Rats fed on either the natural or the purified diet supplemented with $100 \mathrm{~g}$ fat $/ \mathrm{kg}$ had a decreased urinary excretion of NPRO compared with those fed on the corresponding diet without fat, although because of the relatively large standard errors the decrease was not always significant (Table 2). The amounts of NPRO excreted by animals given the low-fat diet varied considerably between the three experiments. It was much lower in the second than in the first experiment using the natural diet and lower still in the experiment with the purified diet. Nevertheless, on both diets butterfat caused a greater proportional reduction in NPRO excretion than any of the other fats tested.

Feeding the butterfat diet did not alter the $24 \mathrm{~h}$ excretion rate of a single oral dose of NPRO (Table 3). The $\mathrm{pH}$ of the stomach contents was similar in animals given the purified diet with or without butterfat and nitrosation (as shown by the formation of NDMA from amidopyrin and nitrite) proceeded equally well in both (Table 4). Although under simulated rat-stomach conditions the fat diets decreased available nitrite in aqueous solution (Table 5), the binding capacity of all the fats was similar and butterfat had no greater effect than the others.

\section{Nitrate reduction experiments}

Nitrite formation by homogenates of stomach tissue plus contents was inhibited by providing butterfat in the diet but no such effect was observed for small intestinal homogenates (Table 6). Results of Expt 7 showed that the physical presence of the butterfat diet was necessary for inhibition of nitrite formation by stomach tissue or contents to occur. In rats fed on the low-fat diet, the activity in stomach contents was significantly reduced by the addition of butterfat diet to the incubation medium when compared with those containing a similar amount of low-fat diet. The reduction in stomach tissue activity by the inclusion of butterfat diet, although large, was not quite significant (Table 7).

A timed feeding period following an overnight fast resulted in stomachs distended with food at the time of sampling. Although a significant reduction in nitrite formation by stomach contents of rats fed on the butterfat diet occurred, tissue activities were similar in rats fed on both diets (Table 8). Nitrite formation in stomach contents was detected only in the forestomach at $\mathrm{pH}$ values above $4(1143,7821$ and $14424 \mu \mathrm{g}$ at $\mathrm{pH} 5,6$ and 7 respectively). No nitrite was found in the contents of the forestomach or glandular stomach 
Table 2. Expts 1-3. Urinary excretion of $\mathrm{N}$-nitrosoproline (NPRO) by conventional (CV) rats fed on diets with or without addition of $100 \mathrm{~g}$ fat $/ \mathrm{kg}$ and $0.235 \mathrm{M}$-sodium nitrate in drinking-water for 3 weeks

(Mean values with their standard errors for four rats)

\begin{tabular}{|c|c|c|c|c|}
\hline \multirow[b]{2}{*}{ Expt } & \multirow[b]{2}{*}{ Diet } & \multicolumn{3}{|c|}{ NPRO excreted } \\
\hline & & $\begin{array}{l}\text { Mean } \\
(n g / d)\end{array}$ & SE & $\begin{array}{c}\text { Percentage of } \\
\text { low-fat } \\
\text { excretion } / d\end{array}$ \\
\hline 17 & $\begin{array}{l}\text { Low fat } \\
\text { Butterfat } \\
\text { Maize oil }\end{array}$ & $\begin{array}{l}721 \\
147^{*} \\
315^{*}\end{array}$ & $\begin{array}{r}151 \\
57 \\
84\end{array}$ & $\begin{array}{r}100 \\
20 \\
44\end{array}$ \\
\hline $2+$ & $\begin{array}{l}\text { Low fat } \\
\text { Coconut oil } \\
\text { Olive oil } \\
\text { Safflower oil }\end{array}$ & $\begin{array}{l}287 \\
181 \\
233 \\
197\end{array}$ & $\begin{array}{l}77 \\
37 \\
45 \\
72\end{array}$ & $\begin{array}{r}100 \\
63 \\
81 \\
69\end{array}$ \\
\hline $3 \S$ & $\begin{array}{l}\text { Low fat } \\
\text { Butterfat } \\
\text { Coconut oil } \\
\text { Olive oil } \\
\text { Maize oil } \\
\text { Safflower oil }\end{array}$ & $\begin{array}{l}210 \\
40^{*} \dagger \\
93^{*} \\
134^{*} \\
72^{*} \\
53^{*} \dagger\end{array}$ & $\begin{array}{r}37 \\
3 \\
23 \\
4 \\
4 \\
7\end{array}$ & $\begin{array}{r}100 \\
19 \\
44 \\
64 \\
34 \\
25\end{array}$ \\
\hline
\end{tabular}

* Mean values were significantly different from those for the low-fat diet $(P<0.05)$.

$\dagger$ Mean values were significantly different from those for the olive-oil diet $(P<0.05)$.

$\$$ Expts 1 and 2 were done with the natural (LAD-2; K \& K Greeff, Croydon, Surrey) diet.

$\$$ Expt 3 was done with a purified diet. For details of composition, see Table 1.

Table 3. Expt 4. Effect of addition of $100 \mathrm{~g}$ butterfat $/ \mathrm{kg}$ to a natural diet (LAD-2;K \& $K$ Greeff, Croydon, Surrey) on the excretion of an oral dose of N-nitrosoproline (NPRO) by conventional rats

(Mean values with their standard errors for four rats)

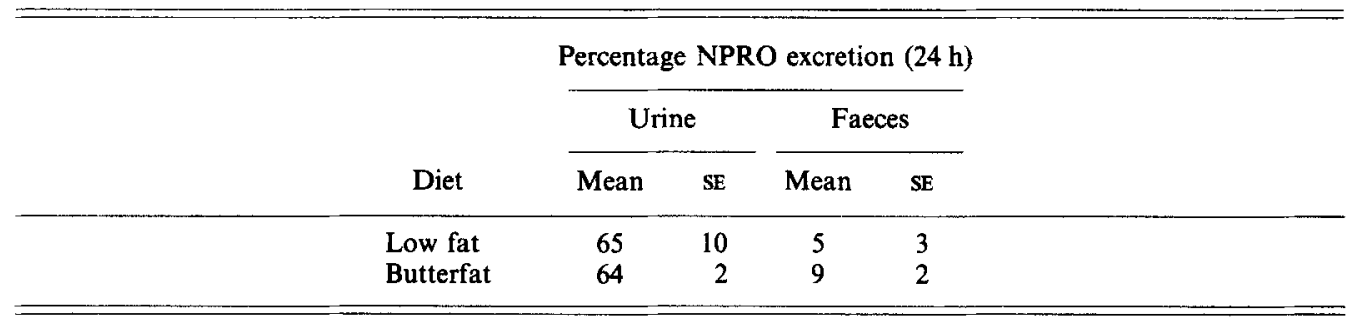

of $\mathrm{GF}$ rats at $\mathrm{pH}$ values ranging from 2 to 7 , indicating that the nitrate reductase activity was of microbial origin. Nitrate reductase activity in GF rat stomach tissue occurred only in the glandular stomach ( $89 \mu \mathrm{g}$ nitrite was formed). The overall activity of the GF stomach tissue was much less than that of the CV rat stomach tissue (Tables 8 and 9) although the experiments are not strictly comparable as they were done on different occasions with different strains of rat.

Fasting reduced nitrate reductase activity in the stomach tissue of both GF and CV rats and low activity was apparently restored after $1 \mathrm{~h}$ feeding in the GF rats (Table 9). The much higher activity of the $\mathrm{CV}$ rat tissue continued to increase through the $6 \mathrm{~h}$ period (Table 8). 
Table 4. Expt 5. Influence of butterfat on the $p H$ and in vitro formation of $\mathrm{N}$ nitrosodimethylamine (NDMA) from $0.1 \mathrm{mmol}$ amidopyrin and $0.1 \mathrm{mmol}$ nitrite by stomach contents of conventional rats fed on a purified diet

(Mean values with their standard errors for ten rats)

\begin{tabular}{|c|c|c|c|c|c|c|c|c|}
\hline \multirow[b]{3}{*}{ Diet } & \multicolumn{4}{|c|}{ Forestomach } & \multicolumn{4}{|c|}{ Glandular stomach } \\
\hline & \multicolumn{2}{|c|}{$\mathrm{pH}$} & \multicolumn{2}{|c|}{ NDMA $(\mu \mathrm{mol})$} & \multicolumn{2}{|c|}{$\mathrm{pH}$} & \multicolumn{2}{|c|}{$\overline{N D M A}(\mu \mathrm{mol})$} \\
\hline & Mean & $\mathrm{SE}$ & Mean & $\mathbf{S E}$ & Mean & $\mathbf{S E}$ & Mean & $\mathrm{SE}$ \\
\hline $\begin{array}{l}\text { Low fat } \\
\text { Butterfat }\end{array}$ & $\begin{array}{l}4.5 \\
4.5\end{array}$ & $\begin{array}{l}0 \cdot 2 \\
0 \cdot 3\end{array}$ & $\begin{array}{l}1.7 \\
0.9\end{array}$ & $\begin{array}{l}0.7 \\
0.2\end{array}$ & $\begin{array}{l}2.8 \\
2.6\end{array}$ & $\begin{array}{l}0.1 \\
0.1\end{array}$ & $\begin{array}{l}5.0 \\
5.5\end{array}$ & $\begin{array}{l}1.5 \\
1.1\end{array}$ \\
\hline
\end{tabular}

Table 5. Expt 6. Scavenging of $0.1 \mathrm{mmol}$ nitrite in aqueous solution at $\mathrm{pH} 4$ and $37^{\circ}$ by purified diets containing $100 \mathrm{~g}$ fat $/ \mathrm{kg}$

(Mean values with their standard errors for three samples)

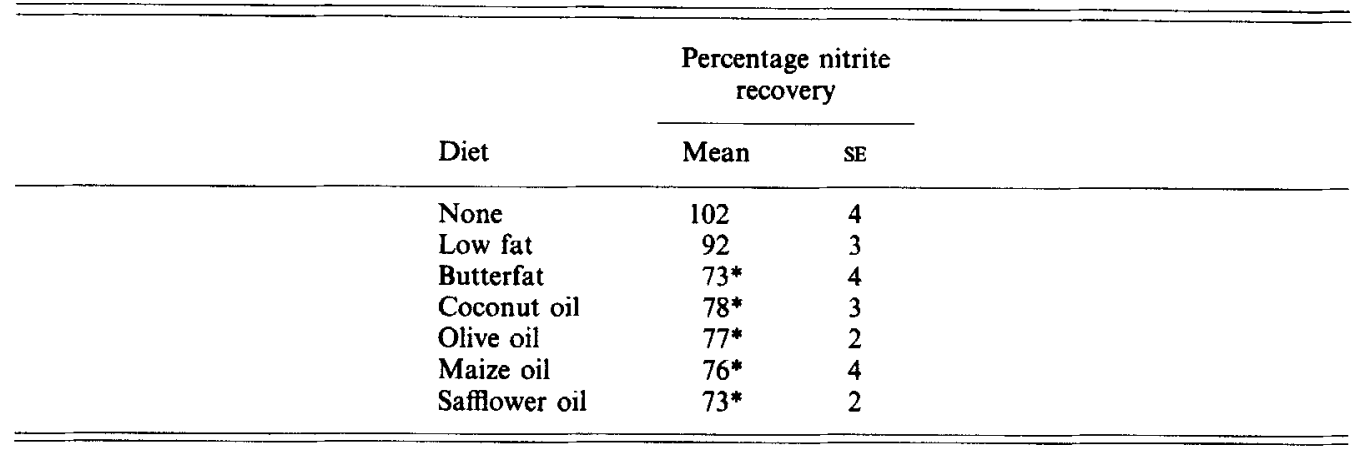

* Mean values were significantly different from the low-fat diet $(P<0.05)$.

In the stomach contents of the fasted $\mathrm{CV}$ rats, nitrate reductase activity was absent but was restored after $1 \mathrm{~h}$ feeding with no significant increase after $6 \mathrm{~h}$ (Table 8).

In experiments in which rats of both sexes were used no influence of sex on the outcome was observed, hence the results from both sexes were pooled.

\section{DISCUSSION}

There was a large difference between Expts 1 and 2 in the excretion of NPRO by rats fed on the low-fat natural diet. The diet was supplied by the same manufacturer but was from different batches and it is known (Wise, 1982) that the composition of natural diets made to a given formula can vary from batch to batch. The differences in NPRO excretion may have been due to differences in concentration of other nitrosatable compounds or inhibitors of $N$-nitrosation present in the natural diet.

The purified diet was not supplemented with proline and the amount of free proline available for nitrosation may have been less than that present in the natural diet containing added proline.

The excretion of NPRO in vivo was decreased by all the fats tested. Among those containing unsaturated fatty acids there appeared to be a positive correlation between fatty acid unsaturation and decreased NPRO excretion, but this may have been due to their 
Table 6. Expt 7. Nitrite formation by homogenates of stomach tissue plus contents of small intestine of conventional rats fed on purified diets with or without $100 \mathrm{~g}$ butterfat $/ \mathrm{kg}$

(Samples were incubated with $0.235 \mathrm{M}$-sodium nitrate in Krebs-Ringer phosphate buffer at $\mathrm{pH} 7.4$ and

$37^{\circ}$ for $24 \mathrm{~h}$. Mean values with their standard errors for six determinations for stomach tissue and twelve determinations for small intestine)

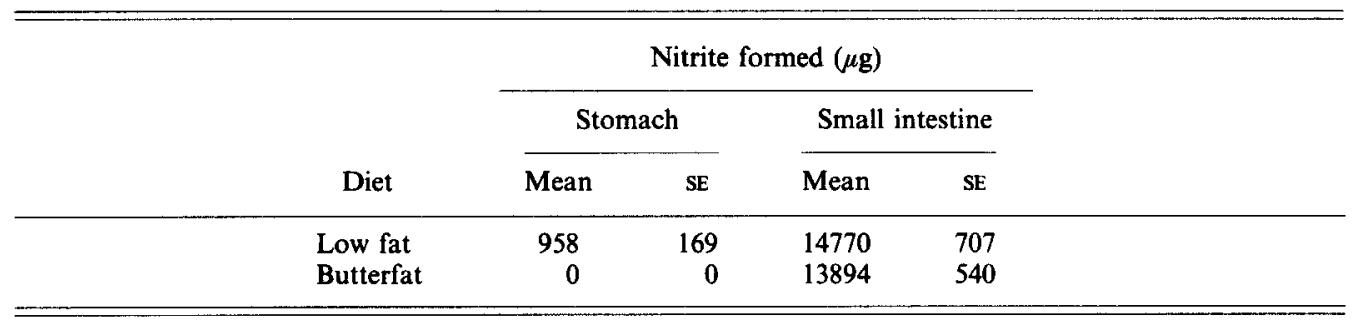

No nitrite was detected in stomach samples incubated at $\mathrm{pH} 4 \cdot 0$.

Table 7. Expt 10. Influence of added low-fat or $100 \mathrm{~g}$ butterfat $/ \mathrm{kg}$ purified diet on nitrite formation by stomach tissue homogenates or contents of conventional rats fed on a purified low-fat diet

(Samples incubated with $0.235 \mathrm{M}$-sodium nitrate in Krebs-Ringer phosphate buffer at pH 7.4 and $37^{\circ}$ for $24 \mathrm{~h}$. Mean values with their standard errors for four rats)

\begin{tabular}{|c|c|c|c|c|}
\hline \multirow[b]{3}{*}{ Diet } & \multicolumn{4}{|c|}{ Nitrite formed $(\mu \mathrm{g})$} \\
\hline & \multicolumn{2}{|c|}{ Whole stomach tissue } & \multicolumn{2}{|c|}{$\begin{array}{l}\text { Whole stomach } \\
\text { contents }\end{array}$} \\
\hline & Mean & SE & Mean & SE \\
\hline Low fat & 6395 & 2681 & $4236^{*}$ & 1055 \\
\hline Butterfat & 3612 & 1521 & $1169^{*}$ & 850 \\
\hline
\end{tabular}

* Mean values were significantly different from each other $(P<0 \cdot 001)$.

Table 8. Expt 11. Influence of fasting followed by a timed feeding period on nitrite formation by stomach tissue homogenates or contents of conventional rats fed on purified diets with or without $100 \mathrm{~g}$ butterfat $/ \mathrm{kg}$

(Samples incubated with $0.235 \mathrm{M}$-sodium nitrate in Krebs-Ringer phosphate buffer at $\mathrm{pH} 7.4$ and $37^{\circ}$ for $24 \mathrm{~h}$. Mean values with their standard errors for four rats)

\begin{tabular}{|c|c|c|c|c|c|c|c|}
\hline \multirow[b]{3}{*}{ Incubate } & \multirow[b]{3}{*}{ Diet } & \multicolumn{6}{|c|}{ Nitrite formed $(\mu \mathrm{g})$} \\
\hline & & \multicolumn{2}{|c|}{ Fasted } & \multicolumn{2}{|c|}{$1 \mathrm{~h}$ refeeding } & \multicolumn{2}{|c|}{$6 \mathrm{~h}$ refeeding } \\
\hline & & Mean & SE & Mean & SE & Mean & SE \\
\hline Whole tissue & $\begin{array}{l}\text { Low fat } \\
\text { Butterfat }\end{array}$ & $\begin{array}{r}11639 \\
8594\end{array}$ & $\begin{array}{r}1636 \\
758\end{array}$ & $\begin{array}{l}13883 \\
13605\end{array}$ & $\begin{array}{r}934 \\
1786\end{array}$ & $\begin{array}{l}23521^{*} \\
24321^{*}\end{array}$ & $\begin{array}{l}1918 \\
3607\end{array}$ \\
\hline Whole contents & $\begin{array}{l}\text { Low fat } \\
\text { Butterfat }\end{array}$ & $\begin{array}{l}0 \\
0\end{array}$ & $\begin{array}{l}0 \\
0\end{array}$ & $\begin{array}{l}6837 \dagger \\
3299\end{array}$ & $\begin{array}{r}1180 \\
880\end{array}$ & $\begin{array}{r}8736 \dagger \\
3305\end{array}$ & $\begin{array}{l}731 \\
789\end{array}$ \\
\hline
\end{tabular}

* Tissue activity significantly different from that of fasted rats and rats fed for $1 \mathrm{~h}(P<0.05)$.

$\dagger$ Contents activity was significantly different from that of butterfat-fed rats $(P<0 \cdot 05)$. 
different $\alpha$-tocopherol contents, as $\alpha$-tocopherol is a known inhibitor of the $N$-nitrosation reaction (Newmark \& Mergens, 1981). Nevertheless, the results for the two fats containing mainly saturated fatty acids suggest that the reaction of nitrous acid with unsaturated bonds is not the predominant mechanism of reduced excretion of $N$-nitrosamines brought about by dietary fats in vivo.

The reduced excretion could have been due to a reduced rate of absorption or excretion of NPRO formed intragastrically as it has been reported that the time-course of NDMA absorption was $6 \mathrm{~h}$ in rats when administered in a maize-oil vehicle and $4 \mathrm{~h}$ in a saline $(9 \mathrm{~g} \mathrm{NaCl} / 1)$ vehicle (Agrelo et al. 1978). In the experiment described here, dietary butterfat did not significantly alter the excretion of NPRO over $24 \mathrm{~h}$ following a single oral dose. NPRO is excreted quantitatively in urine and faeces (Dailey et al. 1975; Chu \& Magee, 1981) and is therefore better suited for this type of study than NDMA which is rapidly metabolized.

$N$-nitrosation of amines in vivo occurs primarily in the acid environment of the stomach. The optimal $\mathrm{pH}$ for $\mathrm{N}$-nitrosation depends on the parent amine but is generally between $\mathrm{pH} 2$ and 5. The presence of butterfat in the diet did not affect either the $\mathrm{pH}$ of rat stomach contents or the yield of NDMA from amidopyrin and nitrite when they were incubated with rat stomach contents. It would appear as though inhibition of the intragastric $N$-nitrosation reaction by dietary fats is not responsible for the decreased nitrosamine excretion. It is, however, possible that the experimental variables chosen, e.g. precursor concentrations, were not suitable to demonstrate an inhibitory effect on intragastric nitrosation by the butterfat diet and further experiments under different conditions are planned. Although the presence of fat in the diet decreased the availability of nitrite in acid solution, the decrease was similar among the fats tested and does not explain the much greater effect of butterfat on nitrosamine excretion.

The absence of nitrite in incubates of whole stomach plus stomach contents of rats fed on a butterfat diet suggested that butterfat was inhibiting nitrate reductase activity in the stomach. The detection of nitrite in incubates, at $\mathrm{pH} 7.4$ but not at $\mathrm{pH} \mathrm{4,} \mathrm{of} \mathrm{whole} \mathrm{stomach}$ plus contents from rats fed on a low-fat diet suggested that nitrate reductase activity in the stomach is purely a mammalian process. Nitrate reductase activity was detected in stomach tissue but not contents of GF rats. However, experiments with stomach contents from CV rats demonstrated that nitrate reductase activity occurred in the forestomach, but only at $\mathrm{pH}$ values higher than $\mathrm{pH} 4$. Furthermore, the activity was absent from stomach contents of fasted CV rats. From these observations it can be inferred that nitrate reductase activity in stomach contents was due to adventitious organisms, e.g. Escherichia coli, ingested with food as the indigenous flora of the rat stomach does not possess nitrate reductase activity (Cole et al. 1985).

Experience in this laboratory indicates that the $\mathrm{pH}$ of rat forestomach contents rises to approximately $\mathrm{pH} 6$ on ingestion of food, probably as a result of the buffering action of the diet. As nitrate reductase activity was only present in stomach contents above $\mathrm{pH} \mathrm{4,} \mathrm{nitrate}$ reduction would therefore only occur in the stomach contents after ingestion of food and not in resting stomach contents. Mammalian nitrate reductase was detected in stomach tissue but was not significantly affected by feeding butterfat in the diet which exerted its inhibitory influence only in stomach contents.

The duration of refeeding did not significantly affect either the nitrate reductase activity of the $\mathrm{CV}$ rat stomach contents or the inhibitory effect of butterfat, which suggests that the flora responsible for nitrate reduction was present in the stomach soon after ingestion of food. The lack of activity in the stomach contents of the fasted rat is consistent with the requirement for a viable flora to be present. Fasting, however, did reduce the tissue nitrate reductase activity both in the GF and CV rats, which is consistent with the known effect 
Table 9. Expt 12. Influence of fasting followed by a timed feeding period on nitrite formation by stomach tissue homogenates or contents of germ-free rats fed on purified diets with or without $100 \mathrm{~g}$ butterfat $/ \mathrm{kg}$

(Samples incubated with $0.235 \mathrm{M}$-sodium nitrate in Krebs-Ringer phosphate buffer at $\mathrm{pH} 7.4$ and $37^{\circ}$ for $24 \mathrm{~h}$. Mean values with their standard errors for four rats)

\begin{tabular}{|c|c|c|c|c|c|c|c|}
\hline \multirow[b]{3}{*}{ Incubate } & \multirow[b]{3}{*}{ Diet } & \multicolumn{6}{|c|}{ Nitrite formed $(\mu \mathrm{g})$} \\
\hline & & \multicolumn{2}{|c|}{ Fasted } & \multicolumn{2}{|c|}{$1 \mathrm{~h}$ refeeding } & \multicolumn{2}{|c|}{$6 \mathrm{~h}$ refeeding } \\
\hline & & Mean & SE & Mean & SE & Mean & SE \\
\hline \multirow[t]{2}{*}{ Whole tissue } & Low fat & 47 & 1 & $63^{\circ}$ & 3 & $61^{*}$ & 6 \\
\hline & Butterfat & 46 & 2 & $59^{*}$ & 3 & 53 & 4 \\
\hline \multirow[t]{2}{*}{ Whole contents } & Low fat & 0 & 0 & 0 & 0 & 0 & 0 \\
\hline & Butterfat & 0 & 0 & 0 & 0 & 0 & 0 \\
\hline
\end{tabular}

* Tissue activity was significantly different from that of fasted rats $(P<0.05)$.

of fasting on mammalian enzyme activity in general (Kato, 1977). The homogenates of CV tissue were very much more active than those of their GF counterparts and it seems likely that at least part of this activity may have resulted from microbial contamination in preparing the homogenates.

The in vitro experiments determined the potential for nitrate reduction, but in vivo the actual amount of nitrite formed would probably be much less. However, the available evidence points to an inhibition of bacterial nitrate reduction by the dietary fats with little discernible effect in the mammalian system. If such is the case, the fat diets should have little effect on nitrosamine excretion in GF rats. This hypothesis is being tested in comparative experiments between $\mathrm{GF}$ and $\mathrm{CV}$ rats fed on different fat diets.

Our studies so far suggest that the reduced excretion of $N$-nitrosamines by animals given high-fat diets is not the result of inhibition of the nitrosation reaction.

The effect can be explained in part by the inhibition of microbial nitrate reductase activity and to a smaller extent by interference with the availability of nitrite. There may also be other contributory factors. Our attention has been mainly focused on butterfat, which caused the greatest reduction in nitrosamine excretion. Further investigations with less-saturated fats are in progress in attempts to elucidate the mechanism.

The authors would like to thank Mrs T. Amor for performing sterility checks on the GF rats and Dr C. L. Walters of the Leatherhead Food Research Association for the use of the GLC-TEA equipment. This work was funded by grants from the Ministry of Agriculture, Fisheries and Food and the International Foundation for the Promotion of Nutrition Research and Nutrition Education.

\section{REFERENCES}

Agrelo, C., Phillips, J. C., Lake, B. G., Longland, R. C. \& Gangolli, S. D. (1978). Toxicology 10, $159-167$.

Cole, C. B., Fuller, R., Mallett, A. K. \& Rowland, I. R. (1985). Journal of Applied Bacteriology 59, $549-553$.

Chu, C. \& Magee, P. N. (1981). Cancer Research 41, 3653-3657.

Dailey, R. E., Braunberg, R. C. \& Blaschka, A. M. (1975). Toxicology 3, 23-28.

Kato, R. (1977). Xenobiotica 7, 25-92.

Kato, T. \& Kikugawa, K. (1984). Food and Chemical Toxicology 22, 419-423. 
Newmark, H. L. \& Mergens, W. J. (1981). In Inhibition of Tumour Induction and Development, pp. 127-168 [M. Zedeck and M. Lipkin, editors]. New York: Plenum Press.

Ohshima, H. (1983). IARC Scientific Publications 45, 333-341.

Shechter, H., Gruenar, N. \& Shuval, H. 1. (1972). Analytica Chimica Acta 60, 93-99.

Ward, F. W., Coates, M. E. \& Walker, R. (1986). Food and Chemical Toxicology 24, 17-22.

Wise, A. (1982). Archives of Toxicology 50, 287-299. 